\title{
ESPAÇO E CULTURA: A REVISTA: ORIGEM E MEIO DE CONHECIMENTO HUMANO
}

\section{- JOSÉ ARILSON XAVIER DE SOUZA'}

Professor do Curso de Geografia e do Programa de Pós-Graduação em Geografia da Universidade Estadual do Maranhão (UEMA), São Luís-MA. Coordenador do Núcleo de Estudos em Território, Cultura e Planejamento (Marielle) e do Grupo de Estudos sobre Espaço e Cultura (GEEC). E-mail: arilsonxavier@yahoo.com.br

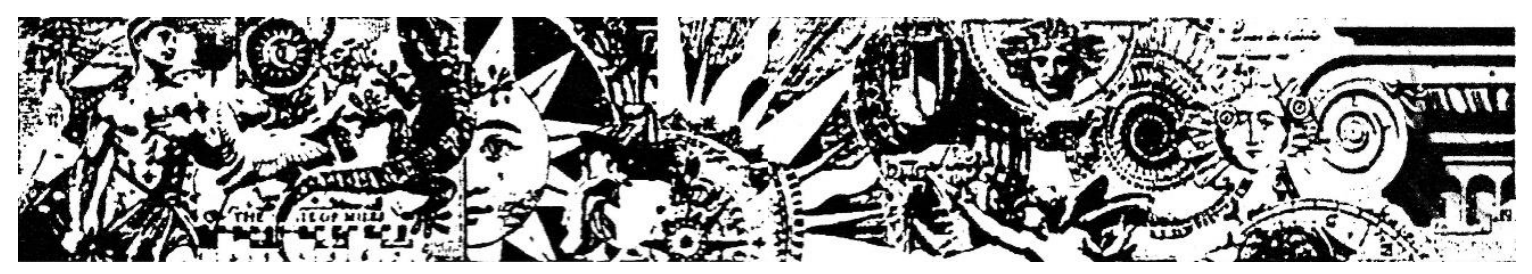

\section{Começo.}

Depoimento. É esta a tônica aqui pretendida para fazermos entreabrir as páginas históricas e geográficas da Revista "Espaço e Cultura", que em muito contribuiu, e continua o fazendo, no tocante à escrita da epistemologia da Geografia brasileira, empreendendo, em especial, um viés cultural para saber-fazer a Ciência.

Deponho, pois, a partir de duas fontes e perspectivas. Da primeira, valendo-me das vivências que alcancei como aluno do Programa de Pós-graduação em Geografia da UERJ (Universidade do Estado do Rio de Janeiro), e, consequentemente, como integrante do Nepec (Núcleo de Estudos e Pesquisas sobre Espaço e Cultural) - lugar e seio pelo qual a "Espaço e Cultura" ganha vida -, algo iniciado em 2013, busco nas minhas lembranças o que escutei e senti da Professora Zeny Rosendahl, minha orientadora de doutorado, a respeito da origem da Revista, palavras que na maioria das vezes foram lançadas ao ar e aos nossos seres durante os seminários de pesquisa que realizávamos nas tardes de terça-feira no Nepec, resenhas que não raro se estendiam pelos andares, corredores e cafés da UERJ/Maracanã-RJ. Já acerca da segunda fonte e perspectiva, lanço mão de um texto traduzido em prosa, que tenciona condensar minha 
interpretação sobre A Revista, movimento que vai desde quando comecei a me debruçar sobre os estudos com abordagem cultural em Geografia - ano 2007 - até os dias de hoje, perpassando, inclusive, o meu pensar para escrever o que está sendo lido.

Notadamente, dizer da origem da Revista traduzia um polo de sentimento muito expressivo para a Professora Zeny. Com um orgulho que parecia lhe saltar da interioridade para a UERJ e da UERJ para o mundo, e do mundo de volta para o seu interior, confundido com a UERJ, com o Nepec, escutei por vezes a Professora falar que a "Espaço e Cultura" nasceu mais ou menos como um gibi, tendo o seu primeiro número impresso e grampeado ali mesmo, no Nepec, como que um artesanato que se faz aos olhos de quem o encomendou. E a encomenda, já naquele contexto - ano 1995 , tinha como parceria o trabalho e orientação do ilustre Professor Roberto Lobato Corrêa, que também não sabia da projeção que a Revista ganharia, material que teria surgido com a pretensão maior de ser utilizado nas aulas desenvolvidas pelos dois.

Ademais, segundo o que ainda hoje os meus ouvidos me dizem é que não podemos deixar de contextualizar o surgimento da Revista com parte do fluxo de vivências profissionais da Professora Zeny. Por ora, reabro o tempo a fim de fazer implicar a sua experiência de doutoramento na USP (Universidade de São Paulo). O ano era 1992, do ato de sua qualificação de pesquisa, oportunidade na qual o Professor da Casa, Heinz Dieter Heidemann, que logo mais viria a ser o seu orientador, leva para este momento alguns números da revista alemã "Geografia Religionum”. Dali então, o geógrafo Manfred Büttner, editor dessa revista, ganhava uma fã: Zeny, uma aspirante à doutora em Geografia que tinha como tema de pesquisa a religião, um tema pouco palatável naquele cenário da Geografia brasileira.

Lembro bem de ver e ouvir a Professora Zeny falar que aquelas revistas lhes serviram, efetivamente, para três coisas, a saber: 1. Salvar a sua pesquisa, que ainda carecia delinear direções; 2. Fazer crer ainda mais na relevância dos estudos geográficos da religião, lhe abrindo novos horizontes conceituais; 3. Instigar, sem que se soubesse, a criação da Revista "Espaço e Cultura". Uma vez terminado o doutorado, retornando à UERJ, criar uma revista significaria instituir, no Brasil, um Meio de resistir e demonstrar a relevância e a plasticidade de uma Geografia que privilegiasse o Espaço e a Cultura enquanto estudo interpretativo de realidades que se superpõe à objetividade. E assim caminhara a deslumbrada recém-doutora, se não com a revista nas mãos, carregava-a no coração, na intenção, compartilhando seus passos com o Lobato, como ela própria o chama. 
Agora, depois de escutar A Professora sobre A Revista, e nas linhas acima ter compartilhado um pouco do que os meus ouvidos me fizeram sentir desse quadro, me incorre, porque me ocorreu, dispensar o seguinte conteúdo-depoimento:

\author{
Espaço e Cultura \\ A Revista \\ Entre dois sinais de dois pontos \\ Meio \\ De Conhecimento Humano \\ Norteado e norteando a Geografia que é Cultural \\ Entre no mundo pelo qual
}

O exame agora ocorre pela leitura do que já foi vivido, desde o começo, se deixando atravessar pelos meios, com saltos aqui e ali, ao exercício de olhares pensativos sobre temas e referências estabelecidas - abaixo pontuo o primeiro e o mais recente número da Revista, sem contar com o número 48, lido por ora em caráter comemorativo. Já o meio fica por conta do investida virtual que cada um pode desfrutar. Como em cultura, o endereço não tem erro, não tem acerto, tem vida, tem ensaios encontrados no link que aparece na nota de roda pé desta página.

O ano: 2020: 25 anos de "Espaço e Cultura". Parabéns e gratidão aos mentores, editores, autores e, sobretudo, aos significativos leitores, por quem a razão ganha sentido, agentes estes que também são potenciais escritores de pesquisas e páginas que estão para serem escritas. E, pela graça do Meio, como condição e conhecimento dos que seguem frente e olham para trás, um desejo à Revista, um frutífero...

\title{
Recomeco....*
}

\section{REFERÊNCIAS BIBLIOGRÁFICAS}

Espaço e Cultura. No 1, 1995. ISSN 2317-4161. Disponível em: https://www.epublicacoes.uerj.br/index.php/espacoecultura/issue/view/271. Acesso em: 29 nov. 2020.

Espaço e Cultura. Dossiê Espacio y religiosidad: miradas desde la Argentina. N $^{\circ}$ 47, jan-jun, 2020. ISSN 2317-4161. Disponível em: https://www.epublicacoes.uerj.br/index.php/espacoecultura/issue/view/2412. Acesso em: 29 nov. 2020. 